\title{
TUGAS POKOK DAN FUNGSI APOTEKER SEBAGAI KEPALA DEPARTEMEN PRODUKSI DI INDUSTRI FARMASI
}

\author{
Putu Wulan Prayascita ${ }^{1}$, Ni Komang Ayu Tri Susanti ${ }^{1}$, Ni Made Febrianti ${ }^{1}$, \\ Ni Luh Cintya Darmia Putri ${ }^{1}$, Ni Made Widi Astuti ${ }^{1}$ \\ ${ }^{1}$ Program Studi Farmasi, Universitas Udayana, Bali, Indonesia, 80361 \\ Email: prayascitawulan@gmail.com
}

\begin{abstract}
ABSTRAK
Produksi sediaan farmasi hanya dapat dilakukan oleh badan usaha yang telah mendapat izin dari Menteri Kesehatan sesuai dengan regulasi yang berlaku. Hal ini menjadi tanggung jawab Apoteker departemen produksi untuk dapat memastikan bahwa proses produksi telah sesuai dengan ketentuan yang berlaku, sehingga dapat mencegah risiko yang dapat merugikan konsumen. Artikel ini bertujuan untuk mengetahui dan menjabarkan tugas pokok dan fungsi Apoteker pada departemen produksi. Metode yang digunakan yaitu deskriptif dengan melakukan studi pustaka terhadap tugas pokok dan fungsi Apoteker pada departemen produksi obat. Apoteker departemen produksi memiliki tugas dan fungsi untuk memastikan pelatihan awal dan berkelanjutan dari personel departemen dan menerapkannya sesuai kebutuhan, memastikan departemen produksi melakukan kualifikasi dan memelihara fasilitas serta peralatan, menyetujui prosedur kegiatan produksi dan memastikan bahwa prosedur tersebut telah sesuai, memastikan bahwa produksi dan penyimpanan obat sesuai dengan prosedur penyimpanan, melakukan evaluasi catatan produksi dan ditandatangani oleh personel berwenang serta telah dilakukan validasi dengan benar. Apoteker dalam departemen produksi memiliki tanggung jawab bersama departemen pemastian mutu dan pengawasan mutu untuk secara bersama-sama melaksanakan semua aspek yang berkaitan dengan mutu, sehingga terbentuk suatu tatanan yang saling berkesinambungan untuk menghasilkan produk obat yang safety, quality, dan efficacy.
\end{abstract}

Kata kunci: Tupoksi, Apoteker, Produksi Obat, Industri Farmasi.

\begin{abstract}
The production of pharmaceutical preparations can only be carried out by business entities that have obtained permission from the Minister of Health in accordance with applicable regulations. It is the responsibility of the pharmacist in the production department to ensure that the production process is in accordance with applicable regulations, so as to prevent risks that can harm consumers. This article aims to identify and describe the main duties and functions of Pharmacists in the production department. The method used is descriptive by conducting a literature study of the main tasks and functions of pharmacists in the drug production department. The production department pharmacist has the duty and function to ensure the initial and continuing training of department personnel and implement it as needed, ensure the production department qualifies and maintains facilities and equipment, approves production activity procedures and ensures that these procedures are in accordance, ensuring that drug production and storage in accordance with storage procedures, evaluating production records and signed by authorized personnel and validated correctly. In addition, Pharmacists in the production department have the joint responsibility of the quality assurance and quality control departments to jointly carry out all aspects related to quality, so as to form a mutually sustainable order to produce medicinal products that are safety, quality, and efficacy.
\end{abstract}

Keywords: Tupoksi, Pharmacists, Drug Production, Pharmaceutical Industry. 


\section{PENDAHULUAN}

Produksi dalam suatu industri farmasi merupakan suatu proses atau kegiatan dari menyiapkan bahan baku kemudian mengolah atau membuatnya menjadi suatu produk hingga pengemasan, menghasilkan dan/atau mengubah bentuk suatu produk sediaan farmasi. Peraturan Pemerintah Republik Indonesia Nomor 72 Tahun 1996 tentang Pengamanan Sediaan Farmasi dan Alat Kesehatan menyatakan bahwa produk suatu sediaan farmasi hanya boleh diproduksi oleh industri yang telah memiliki izin usaha sesuai dengan peraturan perundang-undangan yang berlaku.[1] Peraturan yang mengatur tentang Pekerjaan Kefarmasian, yaitu Peraturan Pemerintah Nomor 51 Tahun 2009 menyatakan bahwa departemen produksi pada suatu industri farmasi harus memiliki Apoteker penanggung jawab dan dibantu oleh Apoteker pendamping dan/atau tenaga teknis kefarmasian lainnya dalam menjalankan tugasnya. [2]

Apoteker yang dipilih menjadi penanggung jawab di departemen produksi harus memahami CPOB (cara pembuatan obat yang baik), memiliki pengetahuan tentang peralatan-peralatan yang digunakan dalam produksi obat, memiliki pengalaman kerja di departemen produksi suatu industri paling sedikit 5 tahun, serta memiliki pengalaman dan pengetahuan di bagian produksi obat dan perencanaan produksi. Hal tersebut dikarenakan Apoteker penanggung jawab yang merupakan kepala produksi bertanggung jawab untuk memastikan bahwa obat yang diproduksi dan disimpan sudah sesuai dan telah memenuhi persyaratan mutu yang ditetapkan. Apoteker sebagai kepala produksi bertanggung jawab dalam kegiatan produksi, seperti memastikan bahwa prosedur telah berjalan dengan ketat sesuai rencana yang telah ditetapkan, memberikan persetujuan terhadap prosedur yang akan dijalankan di bidang produksi, memastikan bahwa catatan produksi telah dievaluasi dan ditandatangani oleh personel yang berwenang dibidangnya. Selain itu, Apoteker yang bertanggung jawab sebagai kepala produksi juga harus memastikan bahwa prosedur pemeliharaan dan kualifikasi peralatan, fasilitas, dan pemeliharaan bangunan di bidang produksi, serta validasi yang tepat telah terlaksana dengan baik. Selanjutnya Apoteker penanggung jawab harus memastikan bahwa pelatihan personel di departemen produksi telah diterapkan dan berjalan sesuai kebutuhan secara berkesinambungan.

\section{METODE PENELITIAN Bahan dan Peralatan}

Bahan yang digunakan pada penelitian ini merupakan data-data atau informasi yang bermanfaat untuk memberikan jawaban terhadap permasalahan yang diteliti. Peralatan yang digunakan berupa telepon genggam dan personal computer.

\section{Metode}

Metode yang digunakan pada penelitian ini adalah metode 
deskriptif, yaitu membuat gambaran terhadap situasi atau fenomena, menerangkan hubungan, menguji hipotesis, membuat prediksi serta mendapatkan makna implisit dari suatu masalah yang ingin dipecahkan.

\section{HASIL dan PEMBAHASAN}

Apoteker memiliki peran dan tanggung jawab di industri farmasi dalam melakukan produksi obat. Salah satu tanggung jawab apoteker di industri farmasi adalah Apoteker penanggung jawab dalam departemen produksi obat. Apoteker sebagai kepala produksi memiliki tanggung jawab sebagai berikut.

1) Pelatihan awal harus dilaksanakan dan diterapkan secara berkesinambungan untuk seluruh personel dalam departemen produksi sesuai dengan standar yang diterapkan.

2) Memastikan kualifikasi dan pemeliharan bangunan, fasilitas serta alat-alat pada bidang produksi sudah dilaksanakan dan diterapkan berdasarkan dengan standar yang berlaku.

3) Persetujuan harus diberikan terhadap Prosedur Tetap (Protap) yang berkaitan dengan kegiatan produksi dan memastikan kegiatan produksi dilaksanakan sesuai dengan prosedur tersebut.

4) Produksi dan penyimpanan obat harus dilaksanakan berdasarkan prosedur yang ditetapkan sehingga menghasilkan mutu obat yang sesuai dengan ketentuan dan prosedur yang berlaku.

5) Catatan produksi harus dipastikan telah mengalami evaluasi dan ditandatangani oleh pihak yang berwenang.

6) Memastikan bahwa validasi yang tepat telah dilaksanakan.

Apoteker dalam departemen produksi memiliki tanggung jawab dalam memastikan bahwa adanya pelatihan awal bagi personel yang akan bekerja di departemen produksi. Hal ini bertujuan agar personel mampu melaksanakan dan menerapkan prosedur yang telah ditetapkan. Pelatihan dilakukan untuk semua personel yang bertanggung jawab di area produksi, gudang/penyimpanan, laboratorium (termasuk personel teknik, perawatan, dan petugas kebersihan), bukan hanya personel kunci [3].

Pelatihan yang dilakukan berupa pelatihan mengenai teori serta penerapan dan pelaksanaan sistem mutu industri farmasi dan CPOB. Materi yang diberikan pada saat pelatihan meliputi pengetahuan dasar CPOB, konsep jaminan kualitas, pemahaman dan penerapan, serta segala tindakan yang sesuai. Materi harus sesuai dengan tugas yang diberikan/dikerjakan oleh personel. Materi juga bisa berupa pelatihan khusus, misalnya bagi mereka yang bekerja pada area dengan tingkat pencemaran yang berbahaya atau berurusan dengan zat aktif dan beracun yang mungkin bisa tertular atau menyebabkan alergi. Selain itu, personel diberikan pelatihan spesifik mengenai tugas yang akan diberikan serta mengenai area bekerja produksi. Metode pelatihan harus mendapat persetujuan dari penanggung jawab departemen terkait, dan harus 
dilakukan secara terus menerus, efektif, dan harus dievaluasi secara teratur, serta catatan pelatihan wajib disimpan [3].

CPOB memberikan persyaratan kepada industri farmasi agar melakukan kualifikasi terhadap aspek kritis kegiatan selama produksi produk obat. Apoteker dalam departemen produksi memiliki tanggung jawab dalam memastikan kualifikasi dan pemeliharaan alat-alat yang digunakan pada bagian produksi sudah dilaksanakan dan diterapkan sesuai dengan ketentuan dan prosedur yang berlaku. Kegiatan kualifikasi mempertimbangkan tahapan dari halhal yang dibutuhkan pengguna hingga pada akhir penggunaan alat-alat produksi, fasilitas, serta sarana penunjang. Spesifikasi Kebutuhan Pengguna (SKP) mencakup standar fasilitas hingga sarana penunjang yang telah ditetapkan sehingga dapat dikatakan bahwa SKP menjadi dasar acuan selama siklus hidup validasi [3].

Seorang Apoteker dalam departemen produksi harus melakukan kualifikasi instalasi terhadap peralatan, fasilitas, dan sarana penunjang atau sistem. Kualifikasi instalasi mencakup verifikasi kebenaran instalasi komponen peralatan yang sesuai dengan gambar teknis, spesifikasi, dan kriteria yang telah ditentukan serta kalibrasi instrumen. Selain itu, Apoteker diharapkan untuk mengumpulkan dan memeriksa prosedur kerja dan pengoperasian serta perawatan dari alat-alat yang akan digunakan dalam proses produksi. Kualifikasi operasional juga perlu dilakukan 74 untuk memahami proses, sistem, dan peralatan serta melakukan konfirmasi mengenai batas operasi atas dan bawah, dan/atau kondisi buruk. Hasil dari kualifikasi ini didokumentasikan pada prosedur operasional, pembersihan, dan perawatan serta pelatihan operator [3].

Seorang Apoteker juga perlu memastikan kualifikasi kinerja yang mencakup melakukan pengujian menggunakan bahan produksi serta pengujian mengenai rentang operasional yang diinginkan sehingga dapat diprediksi jumlah bahan produk yang dibutuhkan serta jumlah produk yang berhasil diproduksi. Kualifikasi ulang terhadap peralatan, fasilitas, sarana penunjang, dan sistem harus dilakukan secara rutin untuk memastikan bahwa kualifikasi terjamin sehingga mutu produk dapat terkendali [3].

Apoteker dalam departemen produksi harus memastikan pelaksanaan pemeliharaan bangunanfasilitas di bagian produksi. Pemeliharaan bangunan-fasilitas pada bagian produksi bertujuan untuk mencegah kontaminasi silang seluruh produk. Pemeliharaan bangunanfasilitas dilakukan dengan memantau ada/tidak hama serangga serta sanitasi dan higiene pada bagian produksi. Apoteker sebagai kepala produksi memiliki tugas dan tanggung jawab dalam membuat prosedur tetap sanitasi ruang produksi serta mengkaji dan memberikan pelatihan prosedur tetap sanitasi ruang produksi pada personel terkait [3].

Higiene pabrik sangat penting untuk dilaksanakan semua elemen 
dalam industri, yang mana perancangan prosedur sanitasi dilakukan oleh berbagai departemen dalam industri. Supervisor dari setiap departemen memiliki tugas untuk mengawasi pelaksanaan prosedur tetap dan dapat memberikan bimbingan serta teguran bahkan pemberian tindakan disipliner atas penerapan prosedur tetap. Semua jajaran staf dan personel yang berada di area produksi dan terlibat langsung di dalamnya, baik secara langsung maupun tidak wajib memperhatikan dan bertanggung jawab terhadap prosedur tetap dengan baik dan benar secara konsisten [3].

Seluruh kegiatan produksi obat dimulai dari seluruh penanganan bahan dan produk jadi, seperti penerimaan dan karantina, pengambilan sampel, penyimpanan, penandaan, penimbangan, pengolahan, pengemasan dan distribusi harus berjalan sesuai dengan prosedur yang berlaku serta dilakukan dokumentasi untuk menghindari terjadinya kesalahan dalam melakukan produksi. Dalam hal ini, Apoteker bertugas dalam pemberian persetujuan mengenai prosedur kegiatan produksi yang dimulai dari perolehan bahan, pengolahan, pengemasan sampai pengiriman obat ke gudang obat jadi dan memastikan bahwa kegiatan produksi dilaksanakan sesuai dengan prosedur tersebut. Pembuatan protap dalam kegiatan produksi diotorisasi oleh Apoteker sebagai kepala produksi dan dibantu oleh kepala pengawasan mutu serta kepala pemastian mutu. Protap dibuat secara konsisten dengan tujuan untuk:

75 a. Proses yang dilaksanakan berjalan konsisten walaupun dijalankan oleh personel yang berbeda.

b. Dipastikan bahwa proses yang dilaksanakan sudah berjalan berdasarkan standar dan ketentuan yang tertera pada CPOB.

c. Mengetahui adanya perubahan proses yang terjadi pada saat pelaksanaan produksi obat.

d. Memudahkan dalam pemberian pelatihan bagi personel baru sehingga dapat memahami tugas dan peran dalam produksi obat.

Protap yang dilaksanakan dan diterapkan dalam industri farmasi harus dikaji dan dipantau secara berkala paling lama dilaksanakan setelah 3 tahun dari masa pembuatan protap. Hal ini bertujuan untuk menghindari adanya kesalahan ataupun kerusakan dalam produksi obat [3].

Apoteker sebagai kepala produksi bertanggung jawab untuk memastikan adanya pelatihan mengenai prosedur tetap pengolahan dan pengemasan kepada operator dan memastikan bahwa prosedur telah dilaksanakan dengan benar. Prosedur pengolahan dan pengemasan yang dilakukan berupa penerimaan bahan awal dan pengemasan primer untuk produksi. Selain itu, bertugas dalam memberikan persetujuan dalam pembuatan prosedur tetap yang terkait dengan kegiatan produksi serta bertanggung jawab dalam melakukan evaluasi dan penandatanganan prosedur pengolahan induk dan pengemasan induk [3]. 
Produksi obat dilaksanakan dengan memenuhi ketentuan CPOB sehingga Apoteker perlu melakukan pemeriksaan catatan pengolahan bets dan catatan pengemasan bets serta menjamin bahwa produksi dilaksanakan sesuai dengan prosedur. Hal ini berkaitan dengan tugas pokok dan fungsi apoteker sebagai kepala produksi dalam melakukan pengawasan produksi obat agar sesuai dengan prosedur dan standar yang berlaku sehingga akan menghasilkan mutu obat yang sesuai dengan prosedur yang ditetapkan. Selain itu, Apoteker juga memastikan catatan selama dilakukan proses produksi telah dilakukan evaluasi dan ditandangani oleh pihak yang berwenang sehingga catatan terus dilakukan perbaharuan agar kualitas mutu produk terus terjaga dengan baik [3].

Apoteker juga memiliki tanggung jawab dalam memastikan validasi yang dilaksanakan pada fasilitas, peralatan, sarana penunjang, dan proses yang digunakan dalam pembuatan obat. Validasi yang dilakukan dapat menggunakan pendekatan secara tradisional atau pendekatan verifikasi secara kontinu. Pendekatan secara tradisional dilakukan dengan memastikan reprodusibilitas sejumlah bets produk yang telah diproduksi berdasarkan prinsip manajemen risiko mutu, sedangkan pada pendekatan verifikasi kontinu dilakukan berdasarkan quality by design (QbD) yang menunjukkan kualitas menurut desain yaitu kualitas harus diintegrasikan dalam setiap proses dari awal hingga akhir produk 76 dan telah ditetapkan secara ilmiah, dengan menggunakan strategi ini dipastikan tingkat kepastian mutu dari produk tinggi [3].

Proses validasi dijalankan oleh produksi, dipantau dan di setujui oleh bagian quality assurance (QA). Proses kalibrasi alat dilakukan secara teratur sesuai jadwal dari masing-masing alat. Perbedaan waktu kalibrasi tergantung dari seberapa rumit dan sering alat tersebut digunakan dalam kegiatan produksi pabrik. Kalibrasi terhadap alat ukur dilakukan menggunakan kalibrator oleh instansi atau kalibrasi nasional. Apoteker bidang kuantifikasi dan validasi melakukan tugasnya sesuai dengan protokol yang telah ditentukan. Apoteker mengevaluasi, menyetujui, dan memelihara laporan tertulis dengan merangkum hasil dan kesimpulan catatan untuk memenuhi persyaratan validasi pada setiap jalannya proses produksi [3].

Pengawasan Mutu, Produksi dan Pemastian Mutu membentuk suatu kolaborasi dalam menjalankan tugas dan tanggung jawab serta menerapkannya dalam segala aspek sesuai kebutuhan. Khususnya pada pelaksanaan desain, pematauan, penjaminan, serta pemeliharaan dari tatanan mutu yang diterapkan dalam industri farmasi hal ini sesuai dengan kajian pada kebijakan BPOM, yang mana penerapan bersama tersebut tertulis dalam CPOB. Ruang lingkup dari CPOB meliputi penanganan serta manajemen mutu, gedung pabrik dan fasilitasnya, personalia setiap departemen, peralatan produksi, sanitasi dan higiene, proses produksi, infeksi diri, audit mutu dari internal 
dan eksternal, pengawasan mutu, penanganan keluhan terhadap produk, recall dan return produk, dokumentasi manual maupun elektronik dari setiap prosedur, pembuatan dan analisis kontrak serta proses validasi dan kualifikasi semua bagian dalam produksi [3].

Selain tugas kepala produksi yang menjamin semua aspek produksi berlangsung dengan baik, ada beberapa tugas dan fungsi dari kolaborasi ketiga departemen (QA, QC (quality control), dan produksi) mulai dari persetujuan dan pemantauan pemasok. Apoteker yang bertugas harus melaksanakan perencanaan dalam pemesanan bahan, kemudian merancang kontrak terhadap pemasok yang telah di setujui. Pembuatan kontrak harus di analisis secara benar dan teliti, untuk menghindari kesalahan dalam prosedur pengiriman bahan baku yang mengakibatkan produk memiliki mutu yang tidak sesuai. Kontrak tersebut berisikan tanda tangan dari apoteker pengadaan yang bertanggung jawab dengan berkas dan kualifikasi bahan di siapkan oleh bagian produksi, pemastian mutu, dan penjamin mutu. Isi kontrak harus jelas berkaitan dengan tanggung jawab dan kewajiban dari pihak industri dan pemasok. Bila kesepakatan telah terbentuk maka pemasok akan mengirim sampel bahan baku yang di pesan oleh industry [3].

Dalam suatu industri pembagian tugas dan prosedur kerja sangat penting sehingga dibentuklah suatu kolaborasi mengenai otorisasi dokumen, prosedur tertulis,dan termasuk amandemen. Departemen produksi menyiapkan dan menyediakan berkas-berkas yang digunakan untuk mengisi klasifikasi atau kesesuaian prosesnya yang digunakan oleh departemen QA dan QC seperti:

a. Seleksi dan penerimaan bahan awal. Pada penerimaan bahan awal harus dilakukan pemberian label yang sesuai kemudian produk-produk di karantina dan ditandai sesuai katagoriyang mana label warna kuning dinyatakan lulus uji oleh QC.

b. Penyiapan berkas dan catatan lengkap pada proses penomoran bets oleh, bagian produksi dan pengecekan kembali dilakukan oleh bagian QA. Nomor bets bertujuan sebagai tanda pengenal, yang memungkinkan dilakukan penelusuran kembali riwayat dari produk jadi pada bets tersebut, Sehingga bahan baku yang rusak mudah untuk ditelusuri penyebabnya. Penanda bets terdiri atas gabungan angka dan huruf.

c. Penimbangan dan penyerahan bahan dilakukan sesuai prosedur tertulis serta diperiksa kembali kebenarannya, bila kepastian bahan baku telah valid maka di tandatangani oleh penanggung jawab produksi.

d. Pengolahan bahan menjadi produk jadi, kondisi daerah pengolahan dipantau dan dikendalikan, dilakukan pemeriksaan terhadap semua peralatan dan bahan yang digunakan. Kegiatan 
pengolahan ini mengikuti prosedur tertulis.

e. Pengemasan bertujuan untuk melindungi produk dari kontaminan dan ketidakstabilan lainnya. Proses pengemasan produk ruahan menjadi produk jadi, memerlukan pengawasan yang saksama untuk menjamin kualitas identitas, dan kelengkapan barang yang sudah dikemas. Tindakan pengemasan mematuhi prosedur tertulis yang telah dirancang sebelumnya.

Kolaborasi yang saling bersinergi antara 3 departemen dalam hal pemantauan dan pengendalian lingkungan industri akan menjamin lingkungan tetap aman dari zat-zat yang bocor akibat kegiatan produksi serta menjamin produk bebas kontaminasi serangga ataupun hewan kecil lainnya. Seperti yang tercantum dalam CPOB dibuat prosedur tetap pengendalian hamayang bertujuan untuk mengendalikan (memperkecil jumlah dan memusnahkan). Kepala Bagian Produksi, Gudang, Pengawasan Mutu, Penelitian, Pengembangan, dan Teknik memiliki tanggung jawab untuk memastikan ada/tidaknya hama serangga di sarana masing-masing bagian.

Tugas yang dilakukan oleh ketiga departemen setelah produk jadi adalah menentukan dan memantau kondisi penyimpanan bahan dan produk. Penyimpanan produk dikategorikan menjadi 3 (tiga) yaitu lulus uji diberi label hijau, label merah produk ditolak dan diberi tulisan DITOLAK, dan label kuning produk dikarantina. Setelah bahan baku diuji dan 78 dinyatakan released, petugas QC akan segera melepaskan rantai dan dilakukan penempelan label released (hijau) oleh petugas gudang. Barang yang dinyatakan tidak lulus oleh QC mendapatkan label rejected (merah) kemudian dipindahkan ke lokasi reject atau ditolak. Penentuan status (ditolak atau lulus) didasarkan pada hasil pemeriksaan. Pelulusan atau penolakan harus dilakukan secara tertulis dan dikomunikasikan ke departemen terkait, misalnya produksi, pengadaan, logistik, dan sebagainya. Tanda pelulusan atau penolakan secara fisik diberikan pada kemasan tersebut dan hal itu dicatat dalam sistem dokumen yang digunakan. Kondisi penyimpanan harus sesuai dengan ketentuan dari departemen penjamin mutu [3].

Penyimpanan catatan merupakan kegiatan yang penting dalam industri farmasi. Tujuan penyimpanan catatan adalah untuk menelusuri kembali proses pembuatan produk melalui bets nya, proses ini dilakukan oleh departemen produksi yang menunjukan hasil kajian terhadap prosedur produk dan departemen QA melakukan kajian ulang bila ada kekeliruan dalam hasilnya. Apabila dalam proses distribusi terjadi masalah dalam stabilitas produk. Penyimpanan dilakukan secara langsung melalui tulisan dan dilakukan juga secara elektronik. Semua personel wajib mengumpulkan setiap catatan pada proses produksi obat [3].

\section{KESIMPULAN}

Peran Apoteker departemen produksi di industri farmasi adalah 
memastikan pelatihan awal dan berkelanjutan untuk personel departemen dan diterapkan sesuai kebutuhan. Memastikan bahwa departemen produksi melakukan kualifikasi dan pemeliharaan fasilitas serta peralatan. Menyetujui dan memastikan prosedur yang terkait dengan kegiatan produksi telah dilakukan secara benar mulai dari penanganan bahan dan produk jadi, seperti penerimaan dan karantina, pengambilan sampel, penyimpanan, penandaan, penimbangan, pengolahan, pengemasan dan distribusi sesuai prosedur yang telah ditetapkan. Memastikan obat yang diproduksi telah disimpan sesuai prosedur yang ditetapkan, memastikan obat yang diproduksi telah disimpan sesuai prosedur penyimpanan, memastikan bahwa catatan selama kegiatan produksi telah dievaluasi dan ditandatangani oleh pihak yang memiliki wewenang dalam mengevaluasi serta telah dilakukan validasi yang benar. Selain itu, Apoteker dalam departemen produksi memiliki tanggung jawab bersama dengan departemen pemastian mutu dan pengawasan mutu untuk menerapkan semua aspek yang berkaitan dengan mutu produk secara bersama sehingga obat yang dihasilkan terjamin keamanan, kualitas, dan khasiatnya.

\section{UCAPAN TERIMA KASIH}

Ucapan terima kasih kepada pihak-pihak yang telah mendukung penelitian, sumber pendanaan maupun dalam penulisan artikel.
DAFTAR PUSTAKA

[1] Presiden RI. Pemerintah Republik Indonesia Nomer 72 Tahun 1996 tentang Pengamanan Sediaan Farmasi dan Alat Kesehatan. Jakarta: Presiden Republik Indonesia; 1996.

[2] Presiden RI. Peraturan Pemerintah Republik Indonesia Nomor 51 Tahun 2009. Jakarta: Presiden Republik Indonesia; 2009.

[3] BPOM RI. Peraturan Kepala Badan Pengawas Obat dan Makanan Republik Indonesia Nomor 34 Tahun 2018 Tentang Pedoman Cara Pembuatan Obat yang Baik. Jakarta: Badan Pengawas Obat dan Makanan Republik Indonesia; 2018. 